\title{
Törö Emese
}

\section{A magyar cafetériarendszer sajátosságai az adójogi változások tükrében}

A cafetériarendszer a munkáltató anyagi ösztönzési rendszerének hatékony kialakításában játszikfontos szerepet. A munkáltatónál alkalmazható javadalmazási rendszer két fö területre osztható: egyrészt a munkabérre, amelynek kifizetése a munkáltatónak jogszabályon alapuló kötelezettsége, másrészt a béren kívüli juttatásokra, amelyek alkalmazása - kevés kivételtől eltekintve - a munkáltató egyoldalú döntésén alapul.

A béren kívüli juttatások adhatóak egy fix rendszer keretében, illetve az egyes munkavállalók eltérő igényeihez igazodva, az általuk kiválasztott formában. Ez utóbbi rendszert, a választható béren kívüli juttatásokat nevezzük cafetériarendszernek. Ennek alkalmazása esetén a munkáltató összeállít egy listát a felkínált juttatásokról és megállapít egy keretösszeget, amelynek erejéig a munkavállalók válogathatnak a „menüböl”. Nagy elönye, hogy egyénre szabottan tudja a munkáltató a munkavállalók különböző igényeit kielégíteni, amelyek változása esetén évenként más-más juttatások igénybevételére ad lehetőséget, ez viszont a munkáltatót terhelő adminisztrációs terheket növeli a fix béren kívüli juttatásokhoz képest. ${ }^{1}$

A fentiekből adódóan, ha a munkáltató minden munkavállalójának választási lehetőség nélkül biztosít valamely béren kívüli juttatást - például étkezési utalványt -, ez még nem jelenti azt, hogy cafetériarendszert müködtet.

A cafetéria elnevezés az angol kávéház szóból ered, ugyanis a munkavállalók - a kávéház vendégeihez hasonlóan - egy menüből választhatnak egy bizonyos összeghatár erejéig.

Az USA-ban kialakult cafetériarendszer az 1990-es években terjedt el világszerte, s Magyarországon is ekkor jelent meg, elsőként az állami tulajdonú nagyvállalatoknál, majd a magántulajdonban lévő közép- és kisvállalkozásoknál is gyorsan elterjedt, előnyös szabályozásából fakadóan pedig napjainkra a közszférában sem ismeretlen. ${ }^{2}$ Népszerüségét támasztja alá, hogy 2008-ban a munkáltatók közel hatvan százaléka müködtetett cafetériarendszert, melynek keretében mintegy 400 milliárd forintnyi értékủ béren kívüli juttatást biztosított dolgozói számára.

2 Lásd bővebben: Ember Alex: A választható béren kívüli juttatások rendszere. Miskolci Jogi Szemle. 2008. 2. szám 121130. 


\section{A cafetériarendszer előnyei és szabályozása}

A béren kívüli juttatások alkalmazása kedvező lehet mind a munkáltató, mind a munkavállaló számára.

Egyik előnye, hogy személyre szabottan, a munkavállalók különböző igényeinek megfelelő juttatások biztosítására ad lehetőséget. A munkabéren felül adott juttatások növelik a munkáltató iránti lojalitást, az elégedettség érzését, a munkáltatói törődést.

A rendszer elterjedtsége hazánkban leginkább az adóterhek csökkentésével volt indokolható, ugyanis a gazdasági válság által előidézett, 2009 nyarán elfogadott megszorító intézkedések bevezetéséig a rendszer összeállítható volt olyan módon, hogy mindkét fél részére adó- és járulékmentesen biztosítsa a juttatások igénybevételét. Így gyakran a béremelés elmaradását kompenzálták a munkáltatók az adómentesen adható és évente változtatható béren kívüli juttatásokkal.

További előnyt jelent a munkavállalóknak, hogy a természetbeni juttatások után nincs semmiféle adókötelezettségük, nem kell adót fizetniük utána és az adóbevallásukban sem kell feltüntetniük, a juttatással kapcsolatos minden költség és adminisztráció a munkáltatót terheli.

\section{Alkalmazási feltételek}

1. Cafetériaszabályzat

A cafetéria alkalmazásának egyik feltétele a munkáltató által egyoldalúan megalkotott belső szabályzat (ún. cafetériaszabályzat), amely tartalmazza a juttatások körét és az igénybevétel feltételeit, s amelynek megismerését valamennyi munkavállaló részére lehetővé kell tenni.

Ebből következik, hogy nem egyedileg az egyes munkavállalókra vonatkozóan állapítja meg a munkáltató a javadalmazás feltételeit, hanem egy mindenkire irányadó belső szabályzatban fekteti le általános jelleggel.

\section{Diszkriminációmentes juttatás}

Kiemelkedő jelentőséggel bír a juttatások diszkriminációmentes igénybevételének a biztosítása, amely úgy valósítható meg, hogy valamennyi munkavállaló részére azonos feltételekkel és azonos módon adnak lehetőséget a juttatások közül a válogatásra. A teljes munkaidőben foglalkoztatottak mellett a részmunkaidős alkalmazottakra is kiterjed a szabályzat hatálya, így a béren kívüli juttatások természetesen őket is megilletik, azonban véleményem szerint nem jelent diszkriminációt számukra a munkaidővel arányos kisebb keretösszeg meghatározása. Kérdésként merül fel, hogy a munkáltatóhoz kirendelt munkavállalók, akik egy másik munkáltatóval állnak munkaviszonyban, jogosultak-e a munkavégzés helyén érvényesülő cafetériajuttatásokra. A kirendelt munkavállalók a munkajogi rendelkezések értelmében ${ }^{3}$ a munkavégzés helye szerinti munkáltató utasításai alapján, az itt érvényesülő munkarend, szabályzatok és kollektív szerződés rendelkezései szerint kötelesek a munkájukat végezni. Véleményem szerint ebből az is következik, hogy a kirendelés idejére ideiglenes jelleggel rájuk is kiterjed a cafetériaszabályzat hatálya.

${ }^{3}$ A Munka Törvénykönyvéről szóló 1992. évi XXII. törvény (Mt.) 106. §. 
A cafetériajuttatások igénybevétele az éves keretösszeg mértékéig lehetséges, amelynek teljes kimerítésére csak az a munkavállaló jogosult, akinek egész évben fennáll a munkaviszonya. Amennyiben valamely munkavállaló évközben létesít munkaviszonyt, úgy időarányosan illetik meg a béren kívüli juttatások.

Kivételesen a belső szabályzat meghatározhatja a juttatások eltérő feltételekkel való igénybevételét is, ez azonban csak abban az esetben jogszerü, ha nem egyénileg, hanem a munkakör, a beosztás, a munkaviszonyban eltöltött idő, az életkor vagy más olyan közös ismérv alapján történik a differenciálás, amely független a munkavégzéssel kapcsolatos teljesítménytöl ${ }^{4}$. Ilyen jellegü különbségtételt fogalmaz meg az önkéntes kölcsönös biztosító pénztárakról szóló törvény, amely a minden pénztártag munkavállalóra nézve egységesen megállapított munkáltatói hozzájárulás mértékének megállapításánál kifejezetten rögzíti korcsoportonként - életkorral növekvő mértékben -- az eltérés lehetőségét azon munkavállalók tekintetében, akik 15 éven belül betöltik a nyugdíjkorhatárt. ${ }^{5} \mathrm{Az}$ eltérő juttatások alkalmazásának másik tipikusan előforduló gyakorlata, hogy a vezető állású alkalmazottak részére más juttatásokat és magasabb keretösszeg erejéig kínál a munkáltató.

Egy tilalom azonban mindenképpen érvényesül: a cafetériajuttatások nem használhatóak fel a végzett munka egyéni, teljesítményarányos díjazására, hiszen erre más juttatási forma - tipikusan a jutalom - szolgál.

\section{Keretösszeg meghatározása}

Az éves keretösszeget a munkáltató határozza meg, s a változó anyagi helyzetétől függően ez évenként más-más összeget jelenthet.

Felső határa nincs, bármilyen összegben adhatóak a béren kívüli juttatások. Korábban érvényesült az adómentesen nyújtható juttatásoknak egy felső határa, amely 2006-2008 között munkavállalónként évi 400000 Ft-ot jelentett. Ez a felső határ 2009-től megszűnt, tehát a juttatások együttes értéke bármekkora összegben adható adómentesen vagy kedvezményes adózással, azonban figyelemmel kell lenni az egyes juttatások egyéni korlátaira, amelyek általában a minimálbérhez, illetve annak meghatározott százalékához igazodnak.

\section{Jogszabályi háttér}

A cafetériarendszerre vonatkozó külön jogszabály nincs, a béren kívüli juttatások alapvető jogszabályi hátterét a személyi jövedelemadóról szóló törvény (továbbiakban: Szja tv.) adja. Mivel e juttatások sok esetben - bár nem kizárólagosan - természetbeni juttatásként kerülnek meghatározásra, így az ezt szabályozó 69 . $\$$ rendelkezései mindenképpen irányadók.

A természetbeni juttatások után az adó mértéke 54 százalék, amelyet a kifizetőnek, vagyis a munkáltatónak kell megfizetnie és bevallania. Az adó alapja az ingyenesen vagy kedvezményesen juttatott termék, szolgáltatás piaci értéke.

\footnotetext{
4 A személyi jövedelemadóról szóló 1995. évi CXVII. törvény (SZJA tv.) 69. §(1) e) pontja.

5 1993. évi XCVI. tv. 12.§ (3)-(4) bekezdése.
} 
Szja tv. 7. \$-a szabályozza az adóalapba nem tartozó tételeket, valamint idesorolhatóak az - azóta jelentősen megnyirbált - 1. sz. mellékletben meghatározott adómentes juttatások, szolgáltatások köre, amelyek között béren kívüli juttatásokkal is találkozhatunk.

Irányadóak még az egyes juttatásokat szabályozó külön jogszabályi rendelkezések, amelyek közül megemlíthető az önkéntes kölcsönös biztosítópénztárakról (Öpt.) ${ }^{6}$ vagy a magánnyugdíjpénztárról (Mpt.) szóló törvény.?

\section{A választható béren kívüli juttatások csoportosítása és köre}

A juttatások csoportosíthatóak az őket terhelő adó mértéke, a jogosultak köre és a juttatások formája alapján.

\section{Az adó mértéke szerint történö csoportositás}

A munkáltató szempontjából lényeges kérdés, hogy mennyibe kerül számára a béren kívül adott juttatás. E szempont alapján három kategóriát állíthatunk fel: a korábban adómentesen nyújtott juttatások többsége kedvezményes adózás alá esik, a juttatások másik köre az általános szabályok szerinti adóterhek megfizetése mellett biztosítható, míg a legszűkebb harmadik csoportba az adómentes juttatások tartoznak.

A cafetériaelemek kedvezményes adózása azt jelenti, hogy a munkáltató 25 százalékos adóval terhelten tudja biztosítani az egyedi összegkorlátok között nyújtott juttatásokat, ezt meghaladóan más közteher-fizetési kötelezettség nem terheli.

Ebbe a kategóriába tartozik a melegétkeztetési juttatás havi 18000 forintot meg nem haladó értéke, amely étkezőhelyi vendéglátás vagy munkahelyi étkeztetés, illetve erre vonatkozó utalvány formájában is adható. Ugyancsak közkedvelt a munkavállalók körében a Magyar Nemzeti Üdülési Alapítvány által kibocsátott, névre szóló üdülési csekk formájában biztosított juttatás, amely a havi minimálbér összegéig kedvezményes adózással adható. Az iskolakezdési támogatást az a munkavállaló veheti igénybe, akinek gyermeke általános iskolában vagy középfokú közoktatási intézmény nappali tagozatán tanul. A juttatás a szeptemberi tanévkezdéshez nyújt anyagi segítséget a szülönek, így annak folyósítására a tanév első napját megelőző és követő hatvan napon belül készpénz vagy utalvány formájában kerülhet sor, amely felhasználható a tankönyvek, tanszerek megvásárlásán túl ruházati termékek beszerzésére is. Kedvezményes adózással az iskolakezdési támogatás gyermekenként a havi minimálbér 30 százalékának megfelelő mértékig juttatható. A munkáltató továbbra is kedvezményesen támogathatja az iskolai rendszerü képzésben résztvevő munkavállalóját, legfeljebb a minimálbér 2,5-szerese értékben. Ebbe az adózási kategóriába tartozik a helyi utazási bérlet munkáltató általi finanszírozása korlátlan összegben. A munkáltató jogszabály alapján köteles megtéríteni a munkavállalóknak a munkába járással összefüggő utazási költségeit. ${ }^{8}$ Ennek értelmében munkába járásnak csak a közigazgatási határon kívülről történő napi munkába járás és hétvégi hazautazás minősül, ha a munkavállaló országos közforgalmú vasúton, elővárosi

\footnotetext{
6 1993. évi XCVI. törvény az önkéntes kölcsönös biztosítópénztárakról,

7 1997. évi LXXXII. törvény a magánnyugdíjról és a magánnyugdijpénztárakról,

8 Mt. 153. § (2) bekezdése és a 78/1993. (V. 12.) korm. rendelet.
} 
vasúton vagy helyközi díjszabással közlekedő helyi és távolsági autóbuszon utazik. Ekkor a költségtérítés mértéke a vasúti bérlet vagy menetjegy értékének 86 százaléka, míg HÉVen és autóbuszon való utazás esetén 80 százalék. A saját gépjárművel történő munkába járás költségeinek megtérítésére csak kivételesen indokolt esetben köteles a munkáltató: kizárólag abban az esetben, ha a tömegközlekedési eszköz nem közlekedik a lakóhely és a munkahely között, ha igénybevétele a munkavállaló munkarendje miatt csak hosszú várakozás mellett lehetne, vagy mozgáskorlátozottsága miatt nem képes tömegközlekedési eszközzel közlekedni. A munkáltató ilyen esetekben az üzemanyag-fogyasztási norma és az APEH által közzétett üzemanyagár alapulvételével számított költségtérítést, valamint $9 \mathrm{Ft} /$ km általános személygépkocsi-normaköltséget köteles kifizetni.

A fenti rendelkezésekből látható, hogy a közigazgatási határon belül történő munkába járással kapcsolatban a munkáltatót nem terheli költségtérítési kötelezettség, azonban béren kívüli juttatásként biztosíthatja, hogy a helyi utazási bérlet árát részben vagy egészben megtérítheti a munkavállalónak. Ennek az a feltétele, hogy a munkavállaló a bérlet megvásárlását a munkáltató nevére kiállított számlával igazolja.

A munkáltató azönkéntes kölcsönös biztosító pénztártag munkavállalójának tagdíjfizetési kötelezettségét egészben vagy részben átvállalhatja munkáltatói hozzájárulásként. A biztosító pénztárak az általuk nyújtott szolgáltatások alapján három csoportba sorolhatóak: a nyugdíjpénztár kizárólag nyugdíjszolgáltatást nyújthat, az önsegélyező pénztár szociális kockázat bekövetkezte esetén kiegészítő ellátást, illetve gyógyszer és gyógyászati segédeszköz árához támogatást biztosíthat, az egészségpénztár pedig a tag betegsége miatti keresőképtelenség esetén a kieső jövedelmének teljes vagy részbeni pótlását, a gyógyszerek árához nyújtott támogatást, valamint a pénztártag halála esetén a hátramaradottak támogatását látja el. (Megjegyzem, a "hátramaradottak” megjelölés nem tartozik az egzakt jogi kategóriák közé, helytállóbb lenne az „eltartott hozzátartozó” kategória használata.) Pénztártag az a természetes személy lehet, aki betöltötte a 16. életévét és a tagdíjfizetését vállalta. A munkáltatói hozzájárulás fizetésének feltétele, hogy a munkáltató is tagja legyen a biztosító pénztárnak. E munkáltatói juttatásnál is érvényesülni kell a diszkriminációmentességnek, hiszen egyetlen olyan munkavállaló sem zárható ki belőle, akinek legalább hat hónapja fennáll a munkaviszonya. A munkáltatói hozzájárulás mértékét is egységesen kell meghatározni, amely történhet azonos összegben vagy a munkabér azonos százalékában. A munkáltatói hozzájárulás kedvezményes adózású összege attól függ, hogy a munkavállaló milyen típusú pénztárnak a tagja: a nyugdíjpénztárba fizetett hozzájárulás havonta a minimálbér 50 százalékáig, míg az egészség- vagy önsegélyező pénztári hozzájárulás a minimálbér 30 százalékáig teljesíthető 25\%-os adóteher mellett. További előnye az önkéntes pénztári tagságnak, hogy a kedvezményezett részére nyújtott szolgáltatás, teljesített kifizetés a magánszemély adómentes bevételének minősül. ${ }^{9}$

A munkáltató egyoldalú kötelezettségvállalása alapján összegszerüségi korlát nélkül 25\%-os adóteher megfizetése mellett vállalhatja a magánnyugdí-pénztár-tag munkavállalók részére a tagdij kiegészités megfizetését.

Fontos hangsúlyozni, hogy a 25\%-os kedvezményes adómérték csak az egyes juttatásoknál meghatározott egyedi korlátig érvényesül, az ezt meghaladó mértékben nyújtott juttatások után az általános szabályok szerint terheli a munkáltatót a közterhek megfizetése, illetve

${ }^{9}$ Szja-törvény 1. sz. melléklet 6.5. és 7.3. pontja. 
egyes juttatások - amelyekre nem vonatkozik a kedvezményes adókulcs - teljes összege után köteles az általános mértékü adót megfizetni.

Az általános adózású juttatások körébe tartozik az egyik legnépszerübb természetbeni juttatás, a hidegétkezési utalvány biztosítása, amelynek teljes összege után a munkáltató a természetbeni juttatásokat terhelő 54 százalékos adó mellett társadalombiztosítási járulék fizetésére is köteles, amelyek összességében 95,58\%-os közterhet tesznek ki. Ez a szinte dupla adóteher arra késztette a munkáltatókat, hogy kedvezményes adózású melegétkezési utalványokat adjanak a munkavállalóiknak, amelyeket azonban nem tudnak olyan széles körben felhasználni, mint a hidegétkezési utalványokat. Álláspontom szerint teljesen szükségtelen a kétféle utalvány megkülönböztetése, célszerübb és egyszerübb lenne a felhasználása, ha az egységes étkezési utalványt - a munkavállaló döntése alapján bármilyen élelmiszer, készétel vásárlására fel lehetne használni.

A munkáltató ajándékutalványt is biztosíthat kupon, bon, jegy formájában, amely csak akkor minősül természetbeni juttatásnak, ha a juttatási feltételek alapján megállapítható, hogy mely termékre vagy szolgáltatásra használható fel.

A kultúrautalvány elnevezéssel elterjedt természetbeni juttatási forma a művelődési intézményi szolgáltatások igénybevételéhez kapcsolódik. Ide tartozik a könyvtári, levéltári, múzeumi szolgáltatás, előadó-művészet, filmvetítés, állat- és növénykert, védett természeti érték bemutatása, közművelődési intézmény által nyújtott felnőtt- és egyéb oktatás, a juttatás formája pedig készpénz nem, csak utalvány, vagyis bérlet és jegy lehet.

Elsősorban a nagyvárosokban élő, fiatal munkavállalók körében népszerű a sporttevékenység végzéséhez nyújtott szolgáltatás cafetériajuttatásként való igénybevétele.

A szabadidősport-tevékenység munkáltatói támogatásához kapcsolódó adójogi szabályok aszerint alakulnak, hogy a sporttevékenység a munkáltató által fenntartott, vagy azon kívüli sportintézményben történik. Ugyanis az Szja tv. csak a saját fenntartású intézményben, sportrendezvényen nyújtott szolgáltatáshoz kapcsolja az adómentességet, ha ezen kívüli sportoláshoz biztosít a munkáltató bérletet, akkor az teljes egészében adóköteles természetbeni juttatásnak minősül.

Az adójogi szempontú csoportosítás harmadik körét az adómentes juttatások képezik. Ebbe a körbe jelenleg a munkáltató által biztosított otthoni számítógép- és internethasználat tartozik.

Akorábbiévekgyakorlatávalmegegyezően továbbraislehetőségvanarra, hogyamunkáltató ingyenesen vagy kedvezményesen, értékhatárra tekintet nélkül adómentesen támogassa a munkavállaló lakásában a számítógép használatát, illetve a magáncélú internet-hozzáférés biztosítását. Ennek nem feltétele az sem, hogy az otthoni munkavégzéssel kapcsolatban kerüljön sor a számítógép és/vagy internet magáncélú használatának finanszírozására. Ez biztosítható olyan módon, hogy a munkáltató fizet elő az internethasználatra, s ennek hozzáférését engedélyezi a munkavállalónak, vagy pedig a munkavállaló nevére szóló számla alapján a munkáltató átvállalja az internet igénybevételéért fizetett összeget.

\section{A jogosultak köre szerinti csoportosítás}

A béren kívüli juttatások fő célja a munkavállalók motiválása, anyagi ösztönzése, így a juttatások többsége kizárólag a munkavállaló részére nyújtható. Vannak azonban olyan juttatások, amelyek szélesebb körben is adhatóak a munkavállalóra vonatkozó kedvezményes adózással. 
Ennek alapján a munkavállaló nemcsak saját, hanem közeli hozzátartozója részére is választhat üdülési csekket, természetesen a saját cafetériakeretének terhére. Nemcsak az aktív, hanem a nyugdijba vonult volt munkavállalójának is biztosíthat a juttatás egyedi korlátjáig kedvezményes adózással a munkáltató üdülési csekket, valamint melegétkeztetést.

Amennyiben a munkáltató vállalja szakképző iskolai tanulók gyakorlati képzését, valamint felsőoktatási intézmények kötelező gyakorlati képzőhelyének minősül, ezekben az esetekben az iskolai tanulót, a hallgatót is megilletheti a gyakorlat idejére étkezési utalvány és üdülési csekk.

\section{A juttatás formája}

A juttatás formája szerinti csoportosítás alapját az adja, hogy egyes juttatásokat kizárólag készpénzben lehet fizetni vagy csakis természetbeni juttatásként nyújtani, addig más juttatásoknál a forma megválasztható.

Kizárólag készpénzben lehet megfizetni az internethasználat diját, a munkáltatói hozzájárulást az önkéntes kölcsönös biztosítópénztárakba, a tagdíj-kiegészítést a magánnyugdíjpénztárakba, a helyi utazási bérlet árát. Az iskolakezdési támogatást pénzben és utalvány formájában is, az ingyenes számítógépet természetben vagy pénzben egyaránt lehet nyújtani. Kizárólag utalványként adható a hidegétkezési utalvány, a melegétkeztetési hozzájárulás utalványként vagy természetben nyújtható az üzemi étkezéshez való hozzájárulással, az üdülési csekk is csak csekk formájában adható, az ajándék-, illetve a kultúrautalvány formája is adott.

Értelmezési kérdést vethet fel a multi-kategóriás ajándékutalványok juttatása, amelyek többféle termékcsoporton belül is felhasználhatóak. A törvény rögzíti, hogy a nevesítés nélküli, bármire felhasználható utalvány nem minősül természetbeni juttatásnak. Azonban a több termékkörre is felhasználható utalványok, amennyiben nevesítik a felhasználhatóság körét (például sportcikkek, szépségápolás, műszaki áruk, élelmiszerek), ugyanúgy megfelelhetnek a természetbeni juttatással szembeni feltételeknek, mint az egy termékcsoportra vonatkozó utalványok.

Az elektronikus adatrögzítés általánossá válásával felvetödik a kérdés, hogy a papír alapú utalványhoz hasonlóan, a meghatározott felhasználási körrel bíró értéktároló kártyák adhatóak-e természetbeni juttatásként. Erre azért nemleges a válasz, mert az értéktároló kártya a Hpt. ${ }^{10}$ alapján elektronikus pénznek minősül, $\mathrm{s}$ a készpénz-helyettesítő fizetési eszközök természetbeni juttatásként nem nyújthatóak.

Összegzésképpen megállapítható, hogy a munkavégzésért járó bérjellegü juttatások kötelező kifizetése mellett a béren kívüli juttatási rendszer alkalmazásának elsődleges célja a munkavállalók elégedettségének fokozása, a dolgozók megtartása, a cafetériarendszer bevezetése pedig biztosítja az egyes alkalmazottak konkrét igényeihez való igazodást. 2010 első negyedévének tapasztalatai azt mutatják, hogy a munkáltatók többsége az adóterhek megnövekedése mellett továbbra is törekszik a korábbi juttatások biztosítására, bár a változatlan mértékü bruttó keretösszeg elköltése esetén az idén kevesebb juttatásban részesülnek a munkavállalók.

${ }^{10}$ A hitelintézetekröl és pénzügyi vállalkozásokról szóló 1996. évi CXII. törvény. 